\title{
O NEGRO HERÓI E A NEGRA ANTI-HEROÍNA: UMA COMPARAÇÃO DISCURSIVA ENTRE RETRATO DO INTRÉPIDO MARINHEIRO SIMÃO E A NEGRA
}

\author{
Edinaldo Gonçalves Coelho ${ }^{1}$ \\ Sorhaya Chediak ${ }^{2}$
}

\begin{abstract}
Resumo
Este estudo apresenta os conceitos de herói e anti-herói na arte acadêmica brasileira, bem como no modernismo brasileiro, a fim de compreender como eles são construídos nas obras Retrato do Intrépido Marinheiro Simão, carvoeiro do vapor Pernambucana, do pintor José Correia de Lima, e $A$ Negra, de Tarsila do Amaral. O objetivo é analisar e contrapor os discursos das representações pictóricas do negro/negra, compreendendo como eles são construídos nestas obras artísticas. O estudo está fundamentado na proposta de leitura de imagens de Carvalho (2011). Ao observar os conceitos de herói e anti-herói nessas obras, é possível perceber que em Retrato do Intrépido Marinheiro Simão predomina o negro idealizado que retoma o estilo neoclássico, em que se hegemonizam os valores estéticos greco-romanos. Já em $A$ Negra prevalece uma anti-heroína que desconstrói estes mesmos valores, construindo outros, apresentando um discurso divergente daquele. Nesse sentido, embora ambas pinturas sejam importantes para a representação negra na arte pictórica brasileira, a obra de Tarsila do Amaral mostra-se mais próxima de uma manifestação artística africana, tendo em vista que engrandece a etnia negra por não idealizar, mas por valorizar, exagerar e desconstruir os preceitos da arte acadêmica.
\end{abstract}

Palavras-chave: A Negra. Retrato do Intrépido Marinheiro Simão. Discurso.

\section{THE BLACK HERO AND THE BLACK ANTI-HEROINE: A DISCURSIVE COMPARISON BETWEEN RETRATO DO INTRÉPIDO MARINHEIRO SIMÃO AND A NEGRA}

\begin{abstract}
This study presents the concepts of hero and anti-hero in Brazilian Academic Art, as well as in Brazilian Modernism, in order to understand how they are built in the works Retrato do Intrépido Marinheiro Simão, carvoeiro do vapor Pernambucana, by the painter José Correia de Lima, and A Negra, by Tarsila do Amaral. The objective is to analyze and compare the discourses of Negro pictorial representations in order to understand how they are raised in these artistic works. The study is based on Carvalho's proposal to read images (2011). When observing the concepts of hero and anti-hero, it is possible to notice that in the work Retrato do Intrépido Marinheiro Simão, the black hero that represents the neoclassicist style prevails, in which the Greek-Roman aesthetic values are hegemonized, whereas in A Negra, an anti-heroine deconstructs these same values, building others, that is, they present divergent discourses. In this sense, although both paintings are important for the black representation in the Brazilian

\footnotetext{
${ }^{1}$ Fundação Universidade Federal de Rondônia (UNIR), Porto Velho - Rondônia - Brasil. Mestre em Estudos Literários pela Universidade Federal de Rondônia (UNIR). Professor de Arte e História do Ensino Médio da rede pública de ensino do Estado de Rondônia. ORCID <http://orcid.org/0000-0001-5204-2382>. E-mail: ednnald@gmail.com.

${ }^{2}$ Pontifícia Universidade Católica de São Paulo (PUC-SP), São Paulo - São Paulo - Brasil. Doutoranda em Língua Portuguesa pela Pontifícia Universidade Católica de São Paulo (PUC-SP). Mestra em Letras pela Universidade Federal de Rondônia (UNIR). Formadora educacional e revisora de textos e materiais didáticos no Núcleo de Formação de professores (SEDUC-RO). ORCID <https://orcid.org/0000-0001-7238-5315>. E-mail: sorhayachediak@seduc.ro.gov.br.
} 


\section{Linguagens - Revista de Letras, Artes e Comunicação - ISSN 1981- 9943 \\ Blumenau, v. 12, n. 2, p. 306-326, mai./ago. 2018. \\ DOI: http://dx.doi.org/10.7867/1981-9943.2018v12n2p306-326}

pictorial field, Tarsila do Amaral's art is closer to an African artistic expression, since it enhances the black ethnicity in a way that it does not idealizes, but it values, exaggerates and deconstructs the precepts of academic art.

Keywords: A Negra. Retrato do Intrépido Marinheiro Simão. Discourse.

\section{INTRODUÇÃo}

Ao analisar as representações do negro nas pinturas brasileiras, produzidas a partir das técnicas acadêmicas do modernismo brasileiro podemos observar algumas concepções estéticas que denotam a representação pictórica ora idealizada/clássica, ora desconstruída/deformada. Enquanto a pintura Retrato do Intrépido Marinheiro Simão, carvoeiro do vapor Pernambucana (1853), de José Correia de Lima apresenta uma concepção clássica de heroísmo, A Negra (1923), de Tarsila do Amaral, desconstrói a idealização da figura humana, ou seja, uma antiheroína, aproximando-se de uma estética originária africana.

Apoiamo-nos nos teóricos Kothe (2000), Brombert (2004) e Feijó (1984) para tratar a questão do herói e do anti-herói e a representação do negro nas duas pinturas. Para tanto, buscamos refletir sobre esses conceitos e perceber qual deles têm maior aproximação com uma concepção artística originária dos povos africanos, a partir dos estudos de Ajzenberg e Munanga (2009).

Na metodologia de análise das pinturas, usamos como base a abordagem de leitura de imagens proposta por Carvalho (2011), fundamentada nos estudos bakhtinianos. Nessa perspectiva, procuramos compreender os discursos pictóricos apoiado em três aspectos: a polifonia, a policromia e a poliesteticia (CARVALHO, 2011). Partindo desses, refletimos sobre a representação do negro na história da arte brasileira, tanto na arte acadêmica do século XIX, como no modernismo no século XX, e, como as ideias sobre o herói e o anti-herói contribuíram para uma ausência da representatividade do negro nas exposições artísticas e nos museus. Entretanto, não faremos um estudo amplo sobre esta temática, uma vez que nossa abordagem consistirá apenas na análise das duas obras mencionadas anteriormente.

Fundamentamos este estudo também nos conhecimentos de Cadilho (2015) que, ao estudar o negro e o mestiço, nas obras de Candido Portinari, apresentou um aparato histórico e destacou a representação dos negros nas obras dos primeiros pintores europeus, que vieram ao Brasil e documentaram paisagens e pessoas brasileiras no período colonial.

\section{A REPRESENTAÇÃO DO NEGRO ANTES DE A NEGRA DE TARSILA DO AMARAL}




\section{Linguagens - Revista de Letras, Artes e Comunicação - ISSN 1981- 9943 \\ Blumenau, v. 12, n. 2, p. 306-326, mai./ago. 2018. \\ DOI: http://dx.doi.org/10.7867/1981-9943.2018v12n2p306-326}

Para sustentar nossas análises, discutiremos a representação de negros/negras em pinturas do período colonial, a fim de perceber como os modelos estéticos eram "importados" da Europa. A abordagem dessa representatividade negra antes da tela de Tarsila do Amaral, fezse necessária porque o discurso pictórico da artista modernista pode, ao nosso olhar, ser entendido como uma forma de rebater este aspecto que tentava "embranquecer" o/a negro/negra. Cadilho (2015) destaca que os primeiros registros imagéticos no período colonial, portanto antes do Modernismo Brasileiro ${ }^{3}$

[...] foram produzidos por artistas viajantes e naturalistas europeus em expedições científicas, que além de virem pesquisar e explorar a natureza brasileira, documentavam as pessoas que aqui habitavam, com interesses diversos na sua divulgação pela Europa. Artistas como Albert Eckhout (1610-1665) e Frans Post (1612-1680) produziram inúmeras imagens da colônia, e Johann Moritz Rugendas (1802-1858), Jean-Baptiste Debret (1768-1848), representaram o Brasil oitocentista, cuja produção nos serve hoje de referência deste período (CADILHO, 2015, p. 22).

A autora ressalta que os quatro pintores são os responsáveis por registrar aspectos do Brasil em telas, desde as paisagens aos retratos de pessoas. É interessante observar que esses artistas, sendo europeus, tinham olhares estereotipados em relação aos negros e indígenas. Assim, é possível perceber, em algumas telas de Eckhout, os negros com características europeias, ou pelo menos com padrões clássicos de beleza, como na pintura a seguir do século XVII (figura 1).

Figura 1. Mulher africana ou Mulher negra, 1641, Albert Eckhout

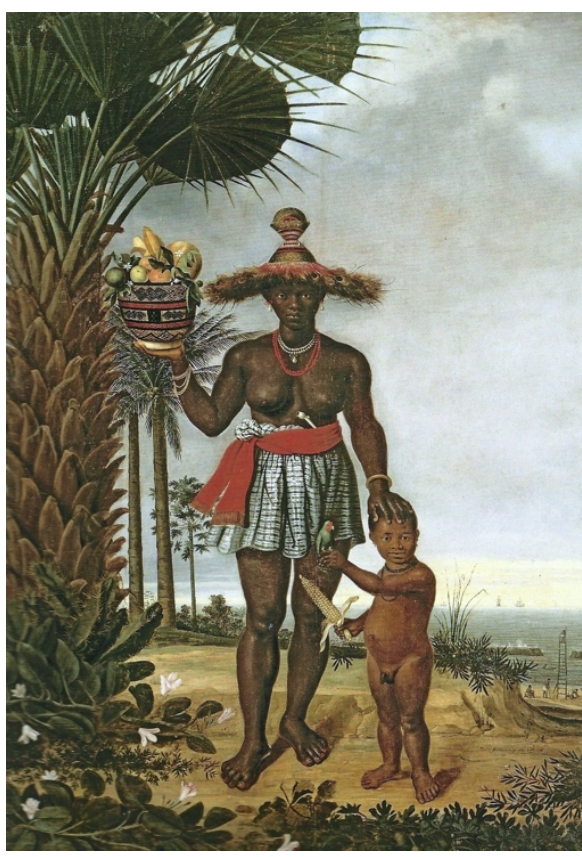

\footnotetext{
${ }^{3}$ Movimento artístico/literário que teve marco inicial com a Semana de Arte Moderna em 1922. Um dos objetivos era romper com a estética artística predominante na época e renovar a partir das experimentações estéticas.
} 


\section{Linguagens - Revista de Letras, Artes e Comunicação - ISSN 1981- 9943 \\ Blumenau, v. 12, n. 2, p. 306-326, mai./ago. 2018. \\ DOI: http://dx.doi.org/10.7867/1981-9943.2018v12n2p306-326}

Fonte: Enciclopédia Itaú Cultural de Arte e Cultura Brasileiras (2017).

Essa obra apresenta um equilíbrio visual, seja pelo emprego de cores sóbrias, centralização da personagem principal ou pela idealização da forma humana conforme os moldes da arte acadêmica, a mulher representada em nada lembra uma escravizada. Além disso, a imagem com elementos exóticos, o chapéu, as frutas na mão esquerda e a saia com um cinto vermelho dão uma certa imponência para a figura feminina. $O$ negro presente na pele da mulher africana ganha um brilho dourado, uma maneira de idealização e disfarce da condição da mulher representada. Para Santos:

Esse empenho em esconder as mazelas da sociedade colonial brasileira fica claro quando analisamos a tela intitulada Mulher Negra. Nesta tela temos a nítida sensação de que a mulher ali representada é uma cidadã livre, não percebemos ali nenhum indício que nos leve a crer que ela é uma escrava, a não ser o fato de sabermos que aquela era uma sociedade com economia baseada no trabalho escravo e que a mesma negra que posou para Eckhout foi também representada por Zacharias Wagener, em seu diário visual 15, e tinha em seu peito, marcado a ferros quentes, o monograma de Nassau, indicando que ela realmente era uma escrava (SANTOS, 2016, p. 62).

Já Rugendas e Debret representam o negro escravizado, quase sempre subalternizado e sofrido no cotidiano, ou então, enfatizam o aspecto cultural ligado ao exotismo, como adornos e crenças. Compreendemos que na época essa visão era comum por parte do colonizador, portanto, o negro representado estava em uma perspectiva da inferioridade comparado ao homem branco. Para exemplificar, observamos uma gravura de Rugendas.

Figura 2. Castigo público, 1835, Johann Moritz Rugendas

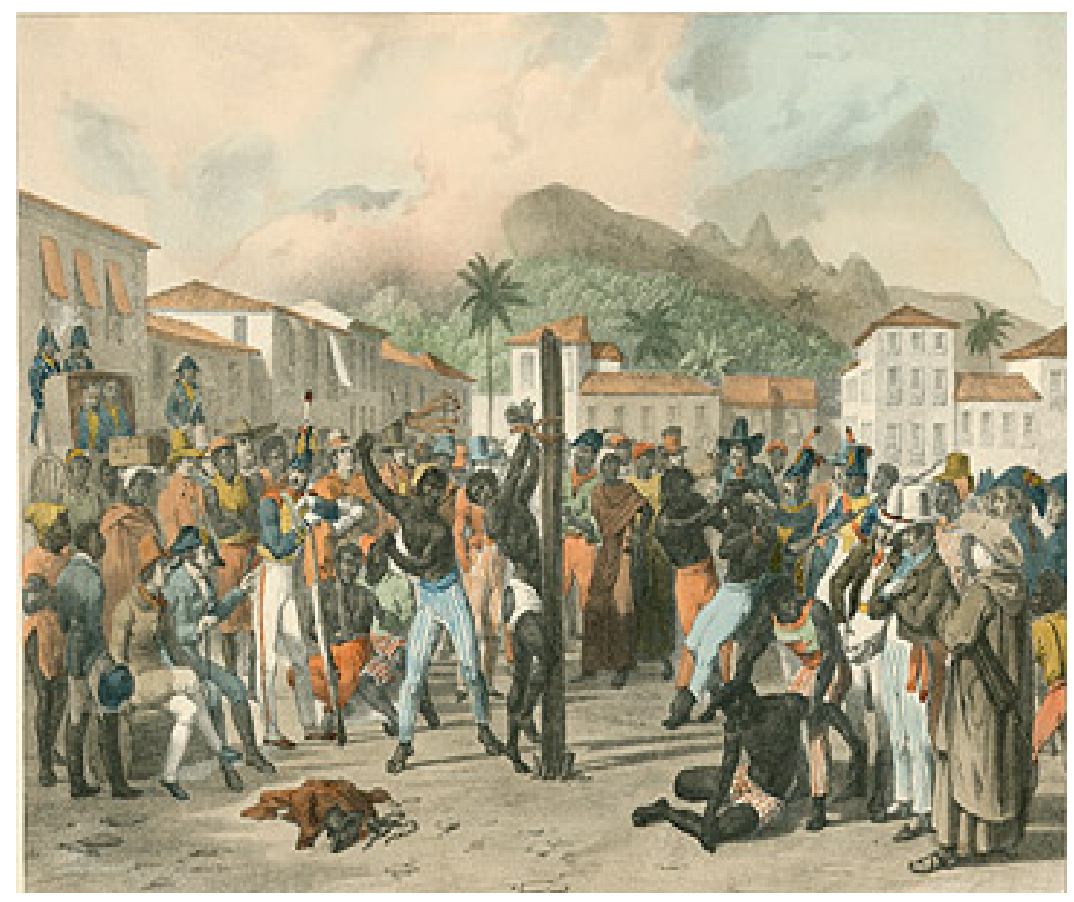




\section{Linguagens - Revista de Letras, Artes e Comunicação - ISSN 1981- 9943 \\ Blumenau, v. 12, n. 2, p. 306-326, mai./ago. 2018. \\ DOI: http://dx.doi.org/10.7867/1981-9943.2018v12n2p306-326}

Fonte: Enciclopédia Itaú Cultural de Arte e Cultura Brasileiras (2016).

Findado o período colonial com a Proclamação da República em 1822, a escravidão não cessou, permanecendo até às últimas décadas do século XIX, ela só foi abolida em $1888^{4}$. Portanto, não era bem visto e nem aceitável, que fossem expostas em museus e salões de exposições artísticas obras que enaltecessem pessoas negras. Cadilho (2015) também evidencia que os primeiros tipos de representações artísticas consideradas nacionais produzidas por artistas brasileiros durante o Brasil colônia:

[...] foram os indígenas, com conotação do habitante originário da terra, em harmonia com a natureza ainda na Literatura Romântica. Como exemplar nas Belas Artes temos a pintura "Moema" (1866), do pintor Victor Meirelles. No final do século XIX, aparece a figura do caipira, do homem rural, mestiço, que sobrevive da terra e carrega em si as enfermidades descobertas de então, mas ícone de um grande potencial de civilização, como "Caipira picando fumo" (1893) do artista José Ferraz de Almeida Junior (CADILHO, 2015, p. 6).

Diante do exposto, compreendemos que não há muita inovação na maneira de representar o/a negro/negra se compararmos com os europeus citados, uma vez que tais pintores, instruídos na arte acadêmica, não representavam negros e indígenas sem uma visão eurocêntrica. Victor Meirelles, ao pintar Moema (1886), representa a personagem mitológica indígena como uma deusa grega e Almeida Júnior pinta um caboclo, em Caipira picando fumo (1893), enaltecendo a tristeza e a solidão da personagem que não é negro, visto que esse esteve praticamente ausente em suas pinturas. Essa ausência do/a negro/a como um personagem elevado nas artes, é esclarecida por Sodré ao afirmar que "O negro não podia ser tomado como assunto, e muito menos como herói [...] porque representava a última camada social. [...] Numa sociedade escravocrata, honrar o negro, valorizar o negro, teria representado uma heresia." (SODRÉ, 1995, p. 268).

Isso explica o motivo que levou muitos artistas a excluírem, ignorarem ou representarem o/a negro/a de maneira estereotipada ou subalternizada, tanto na literatura quanto na pintura. As academias de arte ou as galerias de exposição artísticas não permitiam que houvesse engrandecimento do negro e impediam que pinturas com essas representações fossem admiradas, o que não acontecia com as obras que destacavam os brancos. No entanto, em meados do século XIX acontece uma inovação se considerarmos o contexto do período, visto

\footnotetext{
${ }^{4}$ A Abolição da Escravatura foi oficializada no dia 13 de maio de 1888, após seis dias de votações e debates no Congresso, a Princesa Isabel assinou a Lei Áurea, que decretou a libertação dos escravos no país.
} 


\section{Linguagens - Revista de Letras, Artes e Comunicação - ISSN 1981- 9943 \\ Blumenau, v. 12, n. 2, p. 306-326, mai./ago. 2018. \\ DOI: http://dx.doi.org/10.7867/1981-9943.2018v12n2p306-326}

que José Correia de Lima pintou o Retrato do intrépido marinheiro Simão, carvoeiro do vapor Pernambucana (1853) e, pela primeira vez, um negro foi representado em uma tela devido ao seu heroísmo, entrando em uma galeria de exposição. Analisaremos o porquê dessa aceitação por parte da elite da época, posteriormente.

\section{TARSILA DO AMARAL, A MODERNISTA}

Integrante do Modernismo, Tarsila do Amaral, era de família nobre, teve educação refinada e um reconhecido talento artístico para a pintura. Ela voltou seu olhar poético para os excluídos e deu representatividade a uma grande parcela do povo brasileiro do começo do século XX, mostrou o cotidiano das favelas, desnudou o negro, abordou as festas populares e o trabalho de quem vivia sob a opressão da elite. Como salienta Amaral (1975), em Tarsila Sua Obra e Seu Tempo, Tarsila era neta e filha de fazendeiros, pertencia a uma sociedade de fimde-século, peculiar a São Paulo, e cujo espírito pode ser, em termos, comparável a certo cientificismo que foi a característica do século XIX. Amaral afirma que

\footnotetext{
Embora, ao mesmo tempo, essa sociedade não deixasse de ser, por sua própria estrutura, de classe, fundada no poder da terra, de latifundiários, e do ponto de vista social e político, patriarcal e autoritária dentro do contexto da nação. Ela dava as cartas no Império e ainda dirigia os rumos do país através do poderio do café e dos empreendimentos derivados de seus benefícios nas cidades que se desenvolviam (AMARAL, 1975, p. 9).
}

A pintora, nascida numa família de muitas posses, tradicional e conservadora, tinha tudo para se tornar uma matriarca sossegada. Tendo Capivari, interior de São Paulo, como cidade natal, passou parte da infância na fazenda São Bernardo e outra na fazenda Santa Teresa do Alto "[...] onde as montanhas se sucedem em impressionante desfile de pedras cravejadas e sobrepostas, em formatos variados, origem e estímulo à imaginação" (AMARAL, 1975, p. 17). Por isso, o encanto pela paisagem que tanto via na meninice acompanharia para sempre a carreira pictórica da artista.

Segundo Amaral (1975), a pintora estudou em São Paulo, no Colégio Sion e depois em Barcelona, na Espanha, onde fez seu primeiro quadro, Sagrado Coração de Jesus, em 1904. Quando regressou ao Brasil, já adulta, casou-se com André Teixeira Pinto, com quem teve a única filha, Dulce. Separaram-se alguns anos depois e então ela iniciou seus estudos em arte. Cursou aulas de desenho e pintura no ateliê de Pedro Alexandrino em 1918, onde conheceu a pintora Anita Malfatti. Em 1920, foi estudar em Paris, na Académie Julien, com Émile Renard, 


\section{Linguagens - Revista de Letras, Artes e Comunicação - ISSN 1981- 9943 \\ Blumenau, v. 12, n. 2, p. 306-326, mai./ago. 2018. \\ DOI: http://dx.doi.org/10.7867/1981-9943.2018v12n2p306-326}

onde ficou até junho de 1922, quando soube da Semana de Arte Moderna (que aconteceu em fevereiro de 1922), por meio das cartas da amiga Anita Malfatti.

De acordo com Amaral (1975), as primeiras pinturas de Tarsila mostram sua face impressionista, estudo da luz, pinceladas rápidas e gestos fortes. Entretanto, ela não permaneceu só nessa perspectiva, porque sua poética foi influenciada pelo cubismo quando estudou com o mestre desse movimento, Fernand Léger, e pelo surrealismo.

A criação de $A$ Negra estava ligada à infância da pintora, pois nas fazendas onde viveu, as antigas negras ex-escravizadas e empregadas estavam presentes. É essa tela que marca nosso recorte de análise, sobretudo, por ser a primeira, em que uma negra é protagonista de forma desmistificada e distante da idealização europeia ou sob a visão de inferioridade como fizera Debret e outros pintores.

Em relação às representações de pessoas nas telas de Tarsila é possível observar que a imagem do/a negro/a sempre despertou seu interesse. Seja no retrato como em A Negra, O Pescador (1925), O Vendedor de Frutas (1925), ou nos ambientes paisagísticos como Morro de Favela (1924), O Mamoeiro (1925) e Carnaval em Madureira (1924), entre outras.

Faremos uma análise da tela $A$ Negra, que se caracteriza como um retrato, com o intuito de compreender de que modo a pintora fez a desconstrução da idealização europeia, produzindo uma anti-heroína se comparada às outras representações do/a negro/a como as de Rugendas e Victor Meirelles. Analisaremos também a pintura de José Correia de Lima, Retrato do intrépido marinheiro Simão, carvoeiro do vapor Pernambucana, que também se caracteriza como um retrato, com o propósito de compararmos os discursos desses pintores em relação à questão da representação do/a negro/a como herói ou anti-herói. Entretanto, antes de discutirmos esses conceitos, é necessário compreender a importância do retrato enquanto produtor de sujeitos.

\section{O RETRATO PICTÓRICO COMO PRODUTOR DE SUJEITOS}

O retrato como gênero pictórico é antigo, como exemplificam Souza e Salgado (2016) ao abordarem a questão da origem dos conceitos de retrato e paisagem. Para os autores

O retrato também se fez presente em pinturas rupestres que ainda podem ser encontradas em várias partes do mundo. $\mathrm{Na}$ antiguidade, o Egito nos proporcionou diversos retratos de deuses, líderes e governantes estampados ou esculpidos em vários materiais (madeira, metais, pedras etc.) (SOUZA; SALGADO, 2016, p. 4).

Dessa forma, percebemos que há muito tempo o homem retrata pessoas, uma necessidade de simbolizar que quase sempre esteve associada ao interesse em preservar a 


\title{
Linguagens - Revista de Letras, Artes e Comunicação - ISSN 1981- 9943 \\ Blumenau, v. 12, n. 2, p. 306-326, mai./ago. 2018. \\ DOI: http://dx.doi.org/10.7867/1981-9943.2018v12n2p306-326
}

imagem do sujeito. Por isso, quase não notamos pessoas de classes sociais desfavorecidas retratadas na história da arte com magnitude. Araújo, em relação ao retrato, afirma que:

\begin{abstract}
Pensemos o retrato não como uma reprodução fiel de todas as particularidades do retratado, não como um mero espelho dele, mas como um trabalho de construção do artista a partir do material bruto que tem diante de si. Supomos, assim, que o artista não quer capturar o retratado em qualquer situação, mas numa perspectiva especial digamos, numa situação solene que então é congelada no retrato. Essa situação poderia ser aquela em que o próprio retratado desejasse ser visto pela posteridade, se o trabalho artístico lograsse identificar ou ressaltar algum aspecto essencial da sua personalidade, ou então idealizar, na perspectiva retratada, um tema para sua personalidade (ARAÚJO, 2006, p. 234).
\end{abstract}

Para fazer um retrato nem sempre é preciso de um modelo vivo ou real. Ele pode ser criado também por meio da memória, com as devidas interpretações do artista. Portanto, podemos alegar que a arte de retratar nada mais é que uma "[...] representação de uma figura individual ou de um grupo, elaborada a partir de modelo vivo, documentos, fotografias, ou com o auxílio da memória, o retrato (do latim retrahere, copiar) em seu sentido primeiro ligado à ideia de mimese" (ENCICLOPÉDIA ITAÚ CULTURAL DE ARTE E CULTURA BRASILEIRAS, 2015, s. p., grifos no original). Dito isso, passemos então a analisar as pinturas A Negra, de Tarsila do Amaral, e o Retrato do intrépido marinheiro Simão, carvoeiro do vapor Pernambucana, de Correia de Lima, sabendo que elas podem ser enquadradas como retratos por serem representações de figuras individuais, produzidas com o auxílio da memória.

\section{O DISCURSO PICTÓRICO DE A NEGRA}

A pintura $A$ Negra pode ser considerada um marco para a representatividade negra, porque foi a primeira vez que uma negra, no Brasil, foi representada com tamanha força e imponência, distante dos modelos acadêmicos ou do cotidiano escravocrata como no período colonial. Amaral (1975) afirma que essa obra colocou a pintora Tarsila do Amaral como pioneira da arte modernista brasileira:

\footnotetext{
Pela primeira vez apresentava-se um preto numa tela com destaque e força, conscientização em sua projeção embora inconsciente, posto que Tarsila quase que pintava como envolvida numa atmosfera de irreal, da presença do preto em sua formação, em sua infância, dentro da paisagem que a artista se sentia pertencer, como é assinalado pelas folhas de vegetação (AMARAL, 1975, p. 97).
}

Ao afirmar isso, Amaral (1975) enaltece aspectos que giram em torno da produção da pintura. Provavelmente a presença do/a negro/a na formação da artista desde criança, quase que inconscientemente, a fez trazer uma das negras de suas memórias para tela. Não podemos 


\section{Linguagens - Revista de Letras, Artes e Comunicação - ISSN 1981- 9943 \\ Blumenau, v. 12, n. 2, p. 306-326, mai./ago. 2018. \\ DOI: http://dx.doi.org/10.7867/1981-9943.2018v12n2p306-326}

afirmar que Tarsila quis retratar alguma delas especificamente, mesmo que o nome da tela sugira isso, pois as características enfatizadas na personagem apresentada com lábios grossos, seios grandes e pele negra, não são de apenas uma negra, mas de várias. Dessa maneira, podemos perceber na obra $A$ Negra uma composição a partir de pessoas presentes no cotidiano de sua formação, além da paisagem que a artista observava com frequência na infância. Provavelmente isso venha explicar o verde na pintura, remetendo a vegetação das fazendas.

$\mathrm{Na}$ análise de $A$ Negra, a primeira questão que podemos levantar é sobre a possibilidade de leitura de uma obra pictórica, tomando como fundamento a afirmação de Bakhtin: “[...] tudo que é ideológico possui um significado e remete a algo situado fora de si mesmo. Em outros termos, tudo que é ideológico é um signo. Sem signos não existe ideologia" (BAKHTIN, 2006, p. 29). Desse modo, entendemos que a pintura abordada é um signo e, portanto, uma obra ideológica porque remete a algo fora de si mesma e pode ser lida como qualquer outro texto. Carvalho (2011), reconhece que

[...] a pintura pode ser tomada enquanto um texto, na medida em que traz em sua materialidade elementos básicos que funcionam como registros históricos, retratos de uma sociedade, seus costumes, sua cultura em dada época e espaço, trazendo o passado para o presente, implicando assim analisar a história, a ideologia e a cultura naquele discurso. O pictórico é, portanto, um discurso dinâmico, polissêmico, sempre em construção, aberto a interpretações (CARVALHO, 2011, p. 823).

Sobre os elementos básicos da materialidade da pintura, Dondis (2007, p. 51) afirma que eles "[...] compõem todo discurso pictórico: o ponto, a linha, a forma, a direção, o traço, o tom, a cor, a textura, a dimensão, a escala e o movimento". Bem como afirma Carvalho (2011), tais elementos funcionam como registros históricos, visto que representam as sociedades e culturas de determinadas épocas e espaços, trazendo o passado para o presente. Assim, analisar uma obra pictórica implica contextualizá-la historicamente e socialmente, compreendendo a ideologia predominante nos discursos. Refletindo sobre o processo de leitura de imagens no discurso pictórico, Carvalho (2011) esclarece que é preciso pensar a obra pictórica como

[...] um processo discursivo considerando sua produção de sentidos e, por conseguinte, um sujeito-esteta que é interpelado e atravessado pelo histórico, social, cultural, ideológico. Tem-se assim, um sujeito-esteta inscrito em uma alteridade e por ter essa inscrição em uma alteridade, estará submetido a movências no interior do funcionamento do processo enunciativo, ou seja, nenhum sujeito permanece em um único lugar no interior de um processo enunciativo (CARVALHO, 2011, p. 823).

O sujeito-esteta, segundo a autora, é o artista que discursa ao produzir uma pintura utilizando os elementos básicos da linguagem pictórica, a fim de produzir sentidos. Esses 


\section{Linguagens - Revista de Letras, Artes e Comunicação - ISSN 1981- 9943 Blumenau, v. 12, n. 2, p. 306-326, mai./ago. 2018. \\ DOI: http://dx.doi.org/10.7867/1981-9943.2018v12n2p306-326}

elementos são como as letras na linguagem verbal, pois são organizados na composição pictórica de forma que venham a transmitir significados. Sendo assim, podemos ler a pintura como um texto visual, carregado de significado e dialogismo, em que os elementos básicos podem expressar vozes discursivas.

Sobre o método de ler pinturas, Carvalho (2011) define três termos que devem ser levados em consideração: a polifonia, a policromia e a poliesteticia. O primeiro está relacionado ao discurso filosófico e/ ou político que se manifestam de maneira dialógica entre os elementos da enunciação estética. Já o segundo envolve como as cores se apresentam enquanto evidências de vozes na emissão plástica. Por fim, o último termo interliga vestígio de sinais e vozes que manifestam estilos diversos na materialidade pictórica. A estudiosa ainda afirma que "Polifonicamente, um sujeito-esteta se constitui em várias vozes que dizem respeito a elementos de ordem social, cultural, histórica, filosófica, política, psicológica e estética." (CARVALHO, 2011, p. 826-827).

Para ler A Negra, partimos de uma breve descrição dos elementos básicos pictóricos e, por conseguinte, analisamos a tríade elencada por Carvalho (2011) presente na pintura: a polifonia, a policromia e a poliesteticia. A polifonia pode ser entendida como o elemento de interdiscursividade, isto é, as vozes que dialogam nos textos. Já a policromia implica-se no comportamento das cores utilizadas no espaço pictórico, enunciando algo. Completando a tríade, a poliesteticia é a "[...] unificação entre teoria e prática, na qual um sujeito-esteta condensa-as, para construir sua enunciação, de maneira que possa interpelar um sujeito por meio dos elementos dispostos na tela" (CARVALHO, 2011, p. 827). A intenção é observar como essa tríade compõe o discurso pictórico da obra.

Figura 3. A Negra, 1923, Tarsila do Amaral

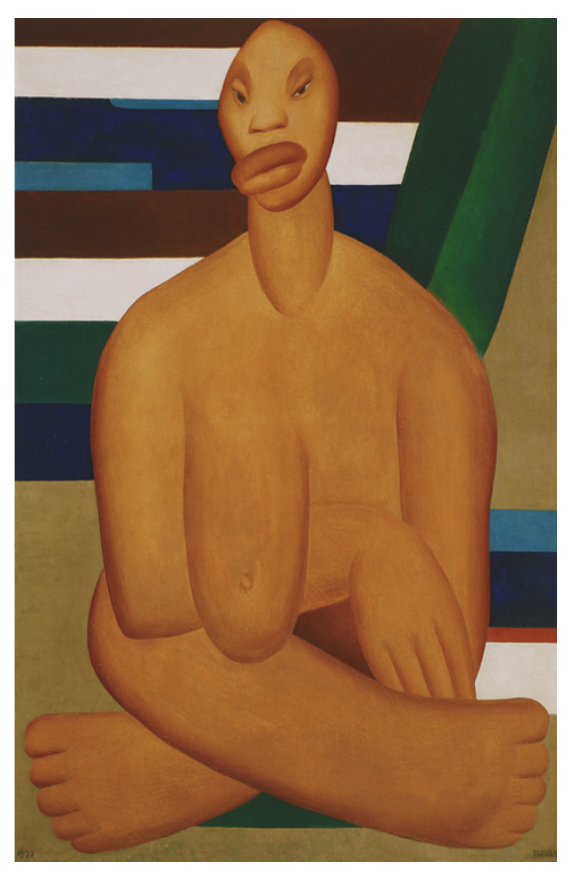




\section{Linguagens - Revista de Letras, Artes e Comunicação - ISSN 1981- 9943 \\ Blumenau, v. 12, n. 2, p. 306-326, mai./ago. 2018. \\ DOI: http://dx.doi.org/10.7867/1981-9943.2018v12n2p306-326}

Fonte: Enciclopédia Itaú Cultural de Arte e Cultura Brasileiras (2017).

Ao explorarmos a pintura, notamos que há dois pontos na parte superior da obra, bem como a predominância de linhas retas, verticais e horizontais, angulares e curvas. Quanto às cores, percebemos alguns matizes: amarelo, azul, verde e algumas variantes tonalidades, como duas do verde, duas do azul, marrom, branco e a cor predominante: uma tonalidade obtida a partir da mistura de duas ou mais matizes, aparentemente amarelo e marrom.

Em relação às formas, na parte superior da tela, podemos notar um conjunto de retângulos horizontais em cores e tamanhos diferentes. No ângulo direito superior uma forma lembrando uma folha de bananeira e, no centro da tela, um personagem estilizado, representando a figura de uma mulher com um seio exageradamente farto, pernas cruzadas, lábios carnudos, olhar fixo, nariz largo e a ausência de cabelos. No que se refere ao plano que a composição é estruturada, predomina o bidimensional, visto que não há a ilusão de profundidade/perspectiva. Podemos destacar dois planos, o primeiro no qual está a figura da mulher negra e o segundo que é composto por figuras geométricas. Após essa descrição formal da obra, passaremos a analisar a tríade e como as vozes do discurso constituem a pintura.

A negra sentada ao centro, nua, com um enorme seio sugere uma referência à ama-deleite, aquelas mulheres negras que no período escravocrata amamentavam os filhos dos donos de escravos. A forma robusta, agigantada, quase primitiva, parece enfatizar a força do/a negro/a como um representante do povo brasileiro. A folha de bananeira se sobressai dentre as formas geométricas na parte superior e reforça o caráter nacional da personagem protagonista. Percebemos que as formas geometrizadas e a estilização da negra remetem ao movimento estético-ideológico cubista, o qual influenciou o sujeito-esteta ao criar a obra.

Observa-se a polifonia da obra no seu discurso ideológico/humanista, ou seja, a artista representou uma figura pouco vista nas pinturas da época, ou ausente no meio artístico elitista. No entanto, ela considerou a relevância dos/as negros/as em sua formação desde criança e a influência na cultura brasileira. Ao relembrar o processo de criação de $A$ Negra, Tarsila do Amaral explicou:

Porque eu tenho reminiscências de ter conhecido uma daquelas antigas escravas que moravam lá na nossa fazenda, e ela tinha os lábios caídos e os seios enormes, porque, me contaram depois, naquele tempo as negras amarravam pedras nos seios para 


\section{Linguagens - Revista de Letras, Artes e Comunicação - ISSN 1981- 9943 \\ Blumenau, v. 12, n. 2, p. 306-326, mai./ago. 2018. \\ DOI: http://dx.doi.org/10.7867/1981-9943.2018v12n2p306-326}

ficarem compridos e elas jogarem para trás e amamentarem a criança presa nas costas. (TARSILA apud GOTLIB, 1998, p. 83).

Provavelmente por esse motivo, enfatiza a grandiosidade e a força da negra pelas formas deformadas. Portanto, podemos considerar que a polifonia contida no discurso está na perspectiva utilizada pela pintura, que ao representar uma negra deformada, enfatiza suas grandiosidades. Ao retratar a partir da memória, a pintora parece combater o discurso pictórico que até então representava o/a negro/a estereotipado/a como fez Albert Eckhout, que optou pelas formas idealizadas e teve como parâmetro a "beleza" clássica, inspirada na arte grecoromana.

A obra $A$ Negra buscou outro caminho, se comparada às pinturas de Johann Moritz Rugendas e Jean-Baptiste Debret, porque estes artistas representaram os/as negros/as como cativos/as, quase sempre mostrando aspectos negativos, como os castigos, o açoite no tronco, a subalternidade perante o branco sem, contudo, problematizar a representação do/a negro/a perante a sociedade discriminatória.

O sujeito-esteta, ao enfatizar o seio farto, parece evidenciar as negras que amamentavam os filhos dos senhores de engenho e dos cafeicultores, que mantinham as amas-de-leite. Ao exagerar nos lábios carnudos, sugere que os padrões de beleza europeus não podem e não devem ser aplicados a todos os povos, tendo em vista que a estética é variável de cultura para cultura. Além disso, enaltece a resistência dos negros que não se conformaram com a subalternidade imposta pelo colonizador.

Analisando o interdiscurso policrômico, percebemos que as cores utilizadas são puras e não há preocupação se elas condizem com o real. Ao pintar a mulher, a artista não tentou ser fidedigna à cor do negro, no entanto evidenciou outras características fenotípicas como lábios e nariz. A pintora utilizou cores variadas nas figuras geométricas e por meio delas, das linhas e das formas, discursou defendendo seu gosto estético, de não ficar presa aos discursos vigentes na academia, que rejeitavam as cores puras por considerá-las caipiras. Pelo contrário, Tarsila rebateu os discursos ao compor uma obra usando essas cores. Podemos observar também o aspecto nacionalista da obra, visto que a cor verde, que preenche a forma de uma folha de bananeira, reporta ao verde tropical brasileiro. Portanto, o matiz verde pode ser entendido como uma característica identitária do Brasil assim como a bananeira.

Sobre a poliesteticia nessa pintura, o discurso humanista da pintora corresponde ao sinal poliestético na representação da negra. Ao usar os elementos pictóricos para criar uma negra "grandiosa" a artista uniu a teoria, ideologia em representar o negro, à prática que transforma a 


\section{Linguagens - Revista de Letras, Artes e Comunicação - ISSN 1981- 9943 \\ Blumenau, v. 12, n. 2, p. 306-326, mai./ago. 2018. \\ DOI: http://dx.doi.org/10.7867/1981-9943.2018v12n2p306-326}

ideologia em pintura. Outro sinal da poliesteticia na obra é a patemia, ou seja, o modo como a artista configurou os elementos pictóricos com o intuito de provocar sensações estéticas nas emoções, como o sobressalto perante a grandiosidade da negra ou, ainda, a admiração.

Dessa forma, a artista compõe a tela com uma negra estilizada. Ao fazer uso de figuras geométricas e cores puras (tons variados), sintetizou o passado e integrou o primitivo (a negra da memória) ao moderno (formas geométricas). Nota-se o engrandecimento da negra na formação da pintora e a universalização como mãe ou ama-de-leite poderia representar a pátria, ou seja, a mãe do povo brasileiro.

\section{JOSÉ CORREIA DE LIMA, O NEOCLASSICISTA}

Antes de A Negra de Tarsila do Amaral, o artista José Correia de Lima pintou o Retrato do intrépido marinheiro Simão, carvoeiro do vapor Pernambucana (1853), uma pintura que colocou um negro como herói. Correia de Lima foi pintor, desenhista, professor e integrou a primeira turma da Academia Imperial de Belas Artes (AIBA). Em 1826 estudou pintura histórica com Jean-Baptiste Debret e arquitetura com Grandjean de Montigny (1776-1850).

Na pintura Retrato do intrépido marinheiro Simão, Correia de Lima alça o negro ao posto de herói, ainda que o personagem tenha sido pintado sob o olhar europeizado, uma influência de sua formação artística. No entanto, a grandiosidade de Simão, o negro representado, está contida em sua história de heroísmo, na qual ele, em certa ocasião, lançouse ao mar e salvou várias pessoas durante um naufrágio em 1853, como esclarece Cadilho

\footnotetext{
Simão, africano de Cabo Verde, homem livre, casado e pai de família, foi eternizado no quadro de José Correia de Lima. [...] Ao analisar o quadro, verificamos que o pintor pretendia transmitir a ideia de que Simão era um homem forte, com peito à mostra $\mathrm{e}$ braço musculoso. Sua cabeça, proporcionalmente menor que o tronco, revela um rosto com muitos detalhes, feição que não demonstra nenhum sentimento ou ação, traço do estilo Neoclássico, reproduzindo os ensinamentos do gênero retrato da Academia (CADILHO, 2015, p. 22-23).
}

Em outras palavras, a proporção observada apresenta-se em consonância com as regras da academia e com a estética alinhada aos valores europeus de aproximação do ideal de belo, clássico, mas distante das características fenotípicas africanas. Além disso, a cor utilizada no herói da pintura foi a dourada, o que pode ser entendido como uma tentativa de aumentar a aceitação da obra pela elite branca, já que o tom de pele negra acabou ofuscado pela cor luminosa-ouro. Nesse sentido, ao realizarmos a leitura desta obra também utilizamos a tríade 


\section{Linguagens - Revista de Letras, Artes e Comunicação - ISSN 1981- 9943 \\ Blumenau, v. 12, n. 2, p. 306-326, mai./ago. 2018. \\ DOI: http://dx.doi.org/10.7867/1981-9943.2018v12n2p306-326}

que compõe o discurso pictórico, segundo Carvalho (2011), assim como o fizemos com $A$ Negra.

No centro da pintura, dentro de uma forma triangular, observamos a figura humana do herói. Cores azuladas, acinzentadas, misturadas em tons escuros e sóbrios, que preenchem o segundo plano vazio da tela. Do lado direito, a claridade dourada emerge e modifica a tonalidade da cor corporal da figura central, deixando-a luminosa-ouro. Temos assim, um retrato em perfeito equilíbrio, como se o retratado tivesse pousado para o pintor e materializado seu heroísmo.

Figura 4. Retrato do intrépido marinheiro Simão, carvoeiro do vapor Pernambucana, 1853, José Correia de Lima.

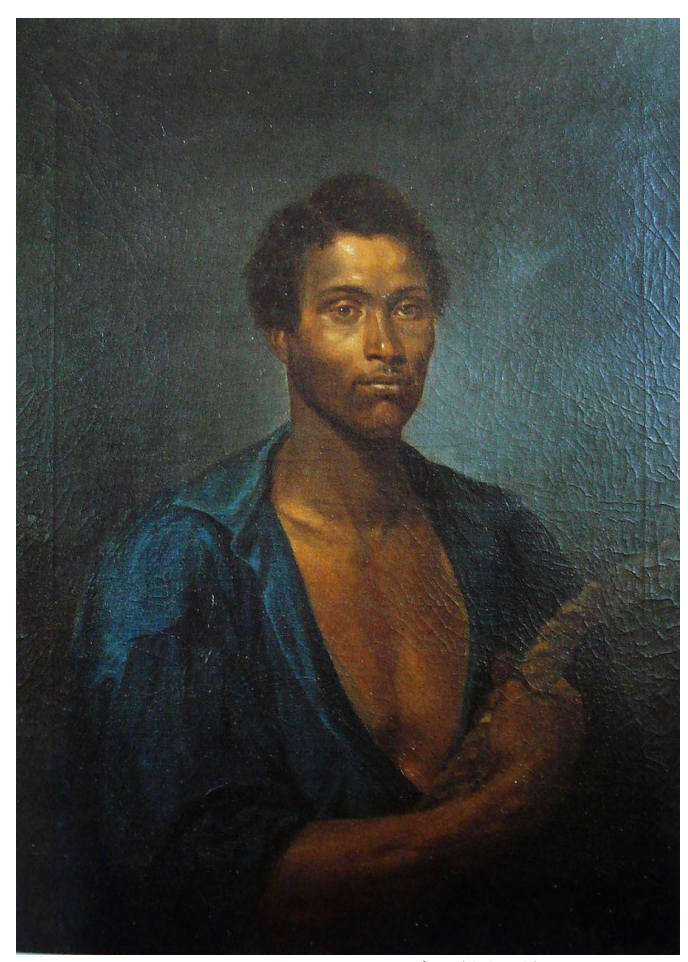

Fonte: Correia (1853).

A representação heroica pode ser entendida também no adjetivo que acompanha o nome de Simão no título da obra, pois intrépido tem o sentido de bravo, corajoso e valente, o que engrandece o retratado. No entanto, o rosto bem detalhado, o peitoral à mostra indicando bravura, o braço forte segurando uma corda, o olhar sereno, a boca pequena e o nariz fino, não condizem com as características dos povos africanos e denunciam a estética neoclássica na obra. Além disso, a cor dourada do tom de pele do herói o embranquece e, simultaneamente, resulta na ilusão de estátua, complementada pela estaticidade do corpo e olhar distante. 


\title{
Linguagens - Revista de Letras, Artes e Comunicação - ISSN 1981- 9943 \\ Blumenau, v. 12, n. 2, p. 306-326, mai./ago. 2018. \\ DOI: http://dx.doi.org/10.7867/1981-9943.2018v12n2p306-326
}

A pintura de Correia de Lima é acadêmica, isto é produzida dentro das regras das academias de arte da época, que se denominavam neoclássicas. Este movimento se caracterizou pela retomada dos valores estéticos greco-romanos, que buscavam a beleza ideal, a harmonia da cor e das formas, sem os exageros do Barroco, destacando a nobreza e a elegância da arte. Nesse contexto, pinturas engrandecendo negros não eram aceitas nos salões de arte, por isso só o ato heroico de Simão foi capaz de colocar sua imagem nos salões de exposições de pinturas. No entanto, para justificar sua presença, o retrato continha uma nota explicando o seu feito. Como observa Cadilho:

\begin{abstract}
Apenas a partir do título da obra e da ciência de sua história, o quadro nos desvela um homem digno pelo seu feito, merecedor de uma pintura a óleo, fugindo à representação em que o negro costumeiramente aparece. Ao denotar valentia, virilidade de maneira dignificante ao intrépido marinheiro, Correia de Lima atesta os pressupostos pedagógicos acadêmicos de ensinar valores éticos e afasta-se da representação que se fazia dos negros no Brasil até meados do século XIX (CADILHO, 2015, p. 24).
\end{abstract}

Neste sentido, o primeiro aspecto a ser observado é a polifonia, ou seja, as várias vozes presentes no texto imagético. Ao pintar um negro como um herói, o sujeito-esteta nega os discursos da academia que eram discriminatórias e excluíam os negros. Se por um lado, enquanto temática, o discurso de Correia de Lima contradiz o dos artistas acadêmicos, quando analisamos a policromia, as cores utilizadas para produzir a pintura, não seguem essa divergência. Nas cores nobres e sutis, observamos harmonia na composição, exploração da luz no efeito claro/escuro.

Notamos um discurso humanista/ético de Correia de Lima, ao destacar o "negro herói”, o pintor o humaniza e mostra que ele pode ser nobre como o homem branco. Apesar da inovação quanto à abordagem do negro nas artes, ainda temos um retrato sob as regras ditadas academicamente, ou seja, o negro foi representado, porém moldado segundo os valores estéticos europeus.

Quanto à poliesteticia, podemos observar que o discurso humanista encontrado na obra é um sinal poliestético, tendo em vista que o artista esteta transformou sua voz e ideologia ao representar a nobreza do negro em uma pintura concretizada. No entanto, o negro representado, conforme o título da obra, é uma pessoa específica, ou seja, aquele negro só poderia ser representado porque fizera um ato heroico, não fora representado por ser negro, mas por ser herói, devido a sua bravura.

Outro sinal poliestético que observamos no discurso são as sensações de nobreza, bravura, calmaria e coragem que a imagem provoca. $\mathrm{O}$ seu aspecto estático, olhar sereno e 


\section{Linguagens - Revista de Letras, Artes e Comunicação - ISSN 1981- 9943 \\ Blumenau, v. 12, n. 2, p. 306-326, mai./ago. 2018. \\ DOI: http://dx.doi.org/10.7867/1981-9943.2018v12n2p306-326}

distante, peitoral à mostra, cores harmoniosas e formas equilibradas, compõem a grandeza daquele negro, digno de uma pintura. Assim, os valores estéticos europeus são empregados na pintura para convencer a elite da época que aquela era uma obra nobre.

\section{O HERÓI E A ANTI-HEROÍNA}

O conceito de herói e anti-herói aplicado nas artes, principalmente na literatura, mostra uma inversão do perfil do herói clássico na modernidade. Ao abordar o herói na história da literatura ocidental, Kothe entende que “[...] o percurso do herói ao longo da literatura ocidental mostra, portanto, uma tendência no sentido de inverter a posição clássica antiga de só admitir, como heróis clássicos elevados, personagens de extração social alta" (KOTHE, 2000, p. 88). Para o autor, a razão dessa inversão seria o processo de industrialização, fazendo com que personagens da classe operária se destacassem, transformando-os em heróis elevados (KOTHE, 2000).

A origem do termo 'herói', do grego heros (nobre, semideus), está diretamente ligada às personagens elevadas da classe alta grega. Feijó afirma que "[...] foram os gregos que deram o nome a eles, como também foram os mitos gregos os que mais sobreviveram, que não se transformaram em religião nem desapareceram. O nascimento do herói, portanto, se deu com o mito" (FEIJÓ, 1984, p. 12). Nesse sentido, o herói clássico era alguém excepcional, capaz de nobres atitudes e com estreita relação com os deuses. Segundo Victor Brombert:

[...] o culto dos heróis havia surgido e se tornara uma espécie de fenômeno religioso. Heróis eram homenageados e reverenciados. Eram associados a uma era mítica em que se dizia que homens e deuses entraram em íntimo contato. Heróis eram seres excepcionais inscritos na lenda, cantados na poesia épica, representados no teatro trágico. (BROMBERT, 2004, p.15).

A respeito da literatura ocidental Kothe alega que "[...] os heróis clássicos são heróis da classe alta, que procuram demonstrar a 'classe' dessa classe" (KOTHE, 2000, p. 12). Isso significa que esses personagens são construídos na linguagem literária grega com muita bravura, capazes de grandes feitos. Nessa direção, Brombert destaca que os "Heróis são desafiadoramente comprometidos com honra e orgulho. [...] o herói é uma figura única, exemplar, cujo fado vai situá-lo no posto avançado da experiência humana, e praticamente fora do tempo" (BROMBERT, 2004, p. 22). Sobre a transformação do herói dos mitos em categoria estética, Feijó enfatiza que “[...] o interesse pelo mito é um interesse poético, são os poetas que dão forma artística às crenças, aos mitos, aos anseios e desejos coletivos" (FEIJÓ, 1984, p. 52). 


\section{Linguagens - Revista de Letras, Artes e Comunicação - ISSN 1981- 9943 \\ Blumenau, v. 12, n. 2, p. 306-326, mai./ago. 2018. \\ DOI: http://dx.doi.org/10.7867/1981-9943.2018v12n2p306-326}

Nessa perspectiva, podemos afirmar que essa transformação do herói mitológico em herói estético vai muito além da literatura, pois o pintor ou o escultor enquanto artistas utilizam a poética também e fazem essa adaptação do mito para a estética artística. Na pintura e na escultura, o herói clássico surge como uma figura sublime, revelando uma concepção de arte grega em que o belo está na idealização das formas da natureza.

Contrapondo-se à figura do herói clássico, temos o anti-herói, construído nas poéticas artísticas, geralmente como uma figura da classe baixa, esse personagem é multifacetado e desconstrói o herói clássico idealizado. Isso acontece, segundo Kothe porque “[...] quando se quer criar um personagem apenas sublime, elevado, acaba-se criando alguém artisticamente baixo porque carente de veracidade. [...] as obras modernas, para poderem ser artisticamente superiores, têm como que uma proibição de heróis positivos e de felicidade" (KOTHE, 2000, p. 58). Nesse aspecto, a pintura de Retrato do Intrépido Marinheiro Simão parece não se encaixar nesse tipo do anti-herói, ao contrário de $A$ Negra.

O anti-herói então vem contestar o herói clássico, já que na modernidade, esse personagem ganha destaque porque parece ter uma maior aproximação com o real, satisfazendo a poética de literatos, pintores, dentre outros artistas. Brombert defende que "[...] esses personagens não são totalmente "fracassos", nem estão desprovidos de coragem; simplesmente chamam a atenção por suas características ajudarem a subverter, esvaziar e contestar a imagem de ideal" (BROMBERT, 2004, p. 19). Nessas concepções de herói e anti-herói, podemos colocar a obra Retrato do Intrépido Marinheiro Simão como um herói muito próximo do clássico e $A$ Negra como uma anti-heroína da modernidade.

\section{COMPARANDO OS DISCURSOS}

Ao analisar os discursos pictóricos presentes nas obras, podemos perceber diferenças entre eles, ainda que os dois engrandeçam o negro e se aproximem no aspecto polifônico, ocorrem diferenças no aspecto policrômico e poliestético. A ruptura estética que marca a obra de Tarsila do Amaral em relação à representação da negra até então, é profunda. Sobre uma breve comparação entre Retrato do Intrépido Marinheiro Simão e A Negra, Cadilho salienta que

Com a ausência de paisagem ao fundo podemos fazer um paralelo com a pintura de Simão, que foi retratado sem a cena da sua história que justificaria a estada do quadro no Salão. O único elemento referente, a corda, se compara com a folha de bananeira, componentes históricos, o primeiro à história pessoal, e o segundo, em referência à 


\section{Linguagens - Revista de Letras, Artes e Comunicação - ISSN 1981- 9943 \\ Blumenau, v. 12, n. 2, p. 306-326, mai./ago. 2018. \\ DOI: http://dx.doi.org/10.7867/1981-9943.2018v12n2p306-326}

história do Brasil, a um ambiente rural no qual esta negra se localizaria (CADILHO, 2015, p. 39).

Como observamos, a autora evidencia a inegável semelhança das obras, dado que a grandeza do/a negro/a em ambas é enfatizada. Porém, existe uma divergência nos discursos, pois Simão só foi representado pelo seu ato nobre, coisa que não acontece em $A$ Negra, que é representada apenas por ser quem é: uma mulher negra. A personagem de Correia de Lima é "aquele negro nobre" e não um negro qualquer, isso não acontece com a personagem pintada por Tarsila, visto que ela é uma mulher negra qualquer, apesar de ser uma lembrança distante da pintora, não foi uma mulher de feito heroico noticiado.

Ambas têm discurso humanista, mas a poliesteticia não é parecida. Tarsila rompeu com regras acadêmicas que ditavam as composições pictóricas, mostrando o negro de forma desnuda, sem idealizações, aproximando-o do primitivismo. Ela também evidenciou a grandeza negra, utilizando a ruptura moderna como uma concepção de desconstrução do herói clássico para aproximá-lo de uma estética africana. Isso é corroborado por Ajzenberg e Munanga (2009), respondendo sobre o que despertou os artistas modernos a buscarem inspirações em esculturas africanas para a produção de pinturas, pois:

Entre várias respostas, uma é constante: o fato de esses artistas terem ficado impressionados com as possibilidades plásticas que daquelas obras se desprendiam. Outra possibilidade era a de encontrar critérios estéticos distintos da visão clássica do mundo ocidental e dos meios tradicionais europeus de representar o objeto plástico (AJZENBERG e MUNANGA, 2009, p. 190).

Nessa perspectiva, é possível observar que em Retrato do Intrépido Marinheiro Simão, que é quase um herói grego porque é composto dentro das normas acadêmicas, com valores estéticos diferentes de uma visão de beleza dos povos africanos, não convence como um herói pela falta de veracidade.

A partir desses discursos dos sujeitos-estetas compreendemos a importância dessas pinturas na história da arte brasileira, sobretudo, na representatividade do/a negro/negra. Enquanto de maneira sutil, Correia de Lima engrandece a representação negra, mostrando um negro nobre, capaz de atos de coragem, inspirado no herói clássico, Tarsila do Amaral, engrandece a representação negra buscando inspirações nas criações artísticas africanas. A artista destaca o aspecto materno e, sobretudo, a força das mulheres negras com uma imagem desconstruída, apontando que o heroísmo não está na idealização. Ao passo que Correia de Lima pinta o negro "herói", Amaral ousadamente pinta a negra "anti-heroína", distanciando as obras e colocando A Negra como a pintura que evidenciou o/a negro/a em uma perspectiva 


\section{Linguagens - Revista de Letras, Artes e Comunicação - ISSN 1981- 9943 \\ Blumenau, v. 12, n. 2, p. 306-326, mai./ago. 2018. \\ DOI: http://dx.doi.org/10.7867/1981-9943.2018v12n2p306-326}

positiva diante das lutas de inclusão, da representatividade da figura negra, nas galerias e exposições artísticas pela sua grandeza natural e bravura comum, longe do herói clássico.

\section{CONSIDERAÇÕES FINAIS}

Este artigo teve como objetivo analisar e comparar os discursos das representações pictóricas do negro/negra nas obras Retrato do Intrépido Marinheiro Simão, Carvoeiro do Vapor Pernambucana do pintor José Correia de Lima e A Negra da pintora Tarsila do Amaral. Por meio da leitura pictórica observou-se três aspectos do discurso: a polifonia, a policromia e a poliesteticia. Para tanto, adotamos a proposta de leituras de imagens de Carvalho (2011), a fim de realizarmos estudos sobre a composição do discurso, bem como observar os interdiscursos, e confrontarmos quais obras têm um caráter positivo em relação à representação negra.

Ao contrastarmos os discursos percebemos que ambas as obras são importantes para a inclusão da imagem do/a negro/a na pintura brasileira, contudo, enfatizamos as diferenças de representação de Correia de Lima e Tarsila do Amaral. Notamos que o pintor criou um negro nos moldes europeus, isso porque ele era filiado ao movimento neoclássico que ideologicamente retomava os valores estéticos greco-romanos. Desse modo, Simão é retratado não por ser um homem negro, mas por ter feito um ato heroico. Sob as regras acadêmicas, o homem cabo-verdiano, transformou-se num "negro europeu", pintado a partir da concepção do herói clássico. Já Tarsila do Amaral fez o oposto disso, uma vez que contrariou as regras acadêmicas e pintou uma mulher negra primitiva ao deformar a figura, aproximando a imagem de uma visão de beleza africana, contrapondo-se aos heróis clássicos. Assim, a negra retratada por Tarsila pode ser considerada uma anti-heroína por ter mais veracidade que aquele idealizado por Correia de Lima.

Ao consideramos o interdiscurso das obras, destacamos o motivo d'A Negra de Tarsila do Amaral ser importante para a representação negra nas artes sem, contudo, diminuir a relevância do retrato de Simão. As leituras e análises das obras nos possibilitaram a percepção de que as respectivas pinturas inovaram no contexto da arte brasileira ao colocar a imagem do/a negro/a nos salões e nas galerias de exposições artísticas. Entretanto, Tarsila do Amaral representou a negra comum, enfatizando sua força sem os valores estéticos clássicos, isto é, buscando inspiração nas manifestações artísticas africanas.

\section{REFERÊNCIAS}


AJZENBERG, E.; MUNANGA, K. Arte moderna e o impulso criador da arte africana. Revista USP, n. 82, p. 189-192, 1 ago. 2009.

AMARAL, Aracy. Tarsila sua obra e seu tempo. Perspectiva/Edusp, 2 v., 1975.

A Negra. In: ENCICLOPÉDIA Itaú Cultural de Arte e Cultura Brasileiras. São Paulo: Itaú Cultural, 2017. Disponível em: <http://enciclopedia.itaucultural.org.br/obra2322/a-negra $>$. Acesso em: 03 de Mar. 2020. Verbete da Enciclopédia. ISBN: 978-85-7979-060-7

ARAUJO, Cicero. Representação, retrato e drama. Lua Nova [online]. n.67, p. 229-260, 2006.

BAKHTIN, Mikhail. Marxismo e filosofia da linguagem. Editora Hucitec. 2006.

BROMBERT, Victor. Em louvor de anti-heróis. São Paulo: Ateliê, 2004.

CADILHO, Carine da C. O negro e o mestiço na pintura de Candido Portinari da década de 1930. 97 f. Dissertação (Mestrado em Relações étnico-raciais) Centro Federal de Educação Tecnológica Celso Suckow da Fonseca, CEFET/RJ, Rio de Janeiro. 2015.

CARVALHO, Sônia F. Elias Mariano. Leitura pictórica: um processo discursivo. Anais do SIELP. Volume 1, Número 1. Uberlândia: EDUFU, 2011.

CASTIGO Público. In: ENCICLOPÉDIA Itaú Cultural de Arte e Cultura Brasileiras. São Paulo: Itaú Cultural, 2016. Disponível em: $<$ http://enciclopedia.itaucultural.org.br/obra5762/ castigo-publico>. Acesso em: 03 de Mar. 2020.

CORREIA de Lima. In: ENCICLOPÉDIA Itaú Cultural de Arte e Cultura Brasileiras. São Paulo: Itaú Cultural, 2017. Disponível em: $<$ http://enciclopedia.itaucultural.org.br/pessoa 22850/correia-de-lima>. Acesso em: 03 de Mar. 2020.

CORREIA, de Lima. Retrato do intrépido marinheiro Simão, carvoeiro do vapor Pernambucana, 1853. Óleo sobre tela, 92 x $72 \mathrm{~cm}$ Rio de Janeiro. Coleção Museu Nacional de Belas Artes.

DONDIS, D. Donis. Sintaxe da linguagem visual. Trad. Jefferson L. Camargo. $3^{\text {a }}$ ed. São Paulo: Martins Fontes, 2007.

FEIJÓ, Martin Cezar. O que é herói. São Paulo: Brasiliense, 1984.

GOTLIB, Nádia Battella. Tarsila do Amaral: a modernista. São Paulo: Editora do Senac, 1998.

KOTHE, Flávio René. O herói. (Série princípios 24) 2ed. São Paulo: Editora Ática, 2000.

MULHER Africana. In: ENCICLOPÉDIA Itaú Cultural de Arte e Cultura Brasileiras. São Paulo: Itaú Cultural, 2017. Disponível em: $<$ http://enciclopedia.itaucultural.org.br/obra24488/ mulher-africana>. Acesso em: 03 de Mar. 2020. 
RETRATO. In: ENCICLOPÉDIA Itaú Cultural de Arte e Cultura Brasileiras. São Paulo: Itaú Cultural, 2015. Disponível em: <http://enciclopedia.itaucultural.org.br/termo364/retrato>. Acesso em: 03 de Mar. 2020.

SANTOS, Izabel Maria dos. Albert Eckhout e o novo mundo: transformação ou manutenção de imaginários? In: Colônia: escritos de história LABORHIS - série monográfica/ Acácio Jose Lopes Catarino... [et Al.], organizadores. - João Pessoa: editora da UFPB, 2016.

SODRÉ, Nelson Werneck. História da literatura brasileira. 9. ed. Rio de Janeiro: Bertrand. Brasil, 1995.

SOUZA, Rodrigo H. B.; SALGADO, I. Retrato e Paisagem: dos primórdios das artes visuais à concepção das fotografias brasileiras na segunda metade do século XIX. In: $4^{\circ}$ COLÓQUIO IBERO-AMERICANO PAISAGEM CULTURAL, PATRIMÔNIO E PROJETO, 2016, Belo Horizonte. 